\title{
Optimasi Penempatan Recloser untuk Meningkatkan Keandalan Menggunakan Metode Virus Evolutionary Genetic Algorithm (VEGA)
}

\author{
Novadianto Yudha Irawan ${ }^{1}$, Anak Agung Ngurah Amrita ${ }^{2}$, Widyadi Setiawan ${ }^{3}$
}

\begin{abstract}
Kutampi Diesel Power Plant that supplies the Lembongan Island electrical system has a reliability value index that has not met the standard with SAIDI 95.85 hours / customer / year and SAIFI 76 times / customer / year while the WCS standard for SAIDI is 2.5 hours / customer / year and SAIFI is 3 times / customers / year. Reliability value can be improved one of them by adding recloser. The addition of the recloser should pay attention to the area of frequent interference, the percentage of load and impedance of the electricity system. The VEGA method was used to determine the optimal recloser location by minimizing the SAIDI and SAIFI values. The result of the optimization method using VEGA shows optimal recloser location in the group 5 with the highest fitness 8,8396 with SAIDI 0,0070 hour / customer / year and SAIFI 0,0061 times / customer / year with program running time \pm 3,6 minutes. These values indicate the VEGA method is more accurate than the fuzzy and genetic algorithm combination method but requires a longer running time.
\end{abstract}

Intisari - PLTD Kutampi yang menyuplai sistem kelistrikan Pulau Lembongan memiliki nilai indeks keandalan yang belum memenuhi standar dengan SAIDI $95,85 \mathrm{jam} /$ pelanggan/ tahun dan SAIFI 76 kali/ pelanggan/ tahun sedangkan standar WCS adalah SAIDI 2,5 jam/ pelanggan/ tahun dan SAIFI $3 \mathrm{kali} /$ pelanggan/ tahun. Nilai keandalan dapat ditingkatkan salah satunya dengan memasang recloser. Pemasangan recloser harus memperhatikan daerah yang sering terjadi gangguan, persentase beban dan impedansi jaringan terpasang. Metode VEGA digunakan untuk menentukan letak recloser optimal dengan meminimalkan nilai SAIDI dan SAIFI. Hasil optimasi menggunakan metode VEGA menunjukkan letak recloser optimal berada pada grup 5 dengan fitness tertinggi 8,8396 dengan SAIDI $0,0070 \mathrm{jam} /$ pelanggan/ tahun dan SAIFI 0,0061 kali/pelanggan/tahun dengan waktu running program $\pm 3,6$ menit. Nilai tersebut menunjukkan metode VEGA lebih akurat dibandingkan dengan metode kombinasi fuzzy dan algoritma genetika namun membutuhkan waktu running lebih lama.

\section{Kata Kunci - Keandalan, Optimasi, Recloser, VEGA}

\footnotetext{
${ }^{1}$ Mahasiwa, Program Studi Teknik Elektro Fakultas Teknik Universitas Udayana, (e-mail: yudhairawan28@yahoo.com)

2 Dosen, Program Studi Teknik Elektro Fakultas Teknik Universitas Udayana (e-mail: amrita_ngr@yahoo.com)

3 Dosen, Program Studi Teknik Elektro Fakultas Teknik Universitas Udayana (e-mail: widyadi@unud.ac.id)
}

\section{PENDAHULUAN}

Ketersediaan energi listrik sangat berperan untuk menunjang majunya suatu kawasan wisata. Pulau Lembongan sebagai salah satu destinasi wisata favorit harus memliliki sistem kelistrikan yang sesuai standar guna menunjang kemajuan pariwisata dan perekonomian warga lokal.

Tahun 2014 sistem kelistrikan Pulau Lembongan yang disuplai dari PLTD Kutampi memiliki nilai indeks keandalan yang belum memenuhi standar dengan SAIDI 95,85 jam/ pelanggan/ tahun dan SAIFI $76 \mathrm{kali} /$ pelanggan/ tahun sedangkan standar WCS adalah SAIDI 2,5 jam/ pelanggan/ tahun dan SAIFI $3 \mathrm{kali} /$ pelanggan/ tahun. Pemasangan recloser pada penyulang merupakan salah satu cara untuk meningkatkan nilai keandalan namun tidak bisa diletakkan disembarang titik melainkan harus memperhatikan daerah yang sering terjadi gangguan, persentase beban dan impedansi jaringan terpasang [1].

Permasalahan tersebut merupakan suatu hal yang kompleks, tidak linier, dan sulit didefinisikan sehingga dibutuhkan teknik komputasi yang berorientasi pada kecerdasan buatan. Teknik optimasi yang paling sering digunakan pada penempatan recloser adalah menggunakan metode Genetic Algorithm (GA). Sudah terdapat beberapa penelitian tentang optimasi penempatan recloser yang menggunakan metode GA dan pengembangannya. Penelitian yang terkait dengan penelitian ini yaitu oleh Putra pada tahun 2016 menggunakan metode kombinasi fuzzy dan GA untuk menentukan letak recloser optimal pada penyulang Lembongan yang belum terpasang recloser. Hasilnya didapatkan 10 referensi letak recloser kemudian dipilih 1 yang memiliki fitness paling tinggi sebagai letak recloser [2].

Penelitian ini menggunakan metode pengembangan GA yang disebut Virus Evolutionary Genetic Algorithm (VEGA). Penggunaan metode VEGA dipilih karena telah dilakukan penelitian oleh Amrita tahun 2007 dengan metode tersebut untuk menentukan posisi bank kapasitor yang bertujuan perbaikan faktor daya dan tegangan sehingga diperoleh rugirugi minimum. Hasil penelitian menunjukkan metode VEGA lebih dapat meminimalkan rugi-rugi daya dibandingkan dengan GA [3]. Penelitian ini diharapkan metode VEGA juga mampu memberikan nilai SAIDI dan SAIFI yang lebih kecil dibandingkan penelitian sebelumnya oleh Putra menggunakan metode kombinasi fuzzy dan GA sehingga didapat penempatan recloser yang optimal. Perbandingan hasil optimasi program VEGA dengan metode kombinasi fuzzy GA dikarenakan kedua penelitian tersebut menggunakan data yang sama yaitu penyulang Lembongan agar nantinya hasil optimasi dapat dibandingkan.

uk... p-ISSN:1693 - 2951; e-ISSN: 2503-2372

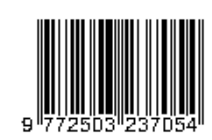




\section{RECLOSER}

Pemutus Balik Otomatis (PBO) atau recloser adalah pemutus tenaga yang dilengkapi dengan peralatan kontrol dan relai penutup balik [4]. Recloser adalah suatu alat otomatis yang mempunyai kemampuan sebagai pemutus arus bila terjadi gangguan hubung singkat yang dilengkapi dengan alat pengindera arus gangguan dan merupakan peralatan pengatur kerja yang telah ditentukan apabila gangguan itu bersifat temporer maka recloser tidak membuka tetap (lock out), kemudian recloser akan menutup kembali setelah gangguan itu hilang. Apabila gangguan bersifat permanen, maka setelah membuka atau menutup balik sebanyak setting yang telah ditentukan kemudian recloser akan membuka tetap (lock out). Bentuk fisik recloser ditunjukkan pada gambar 1 [5].
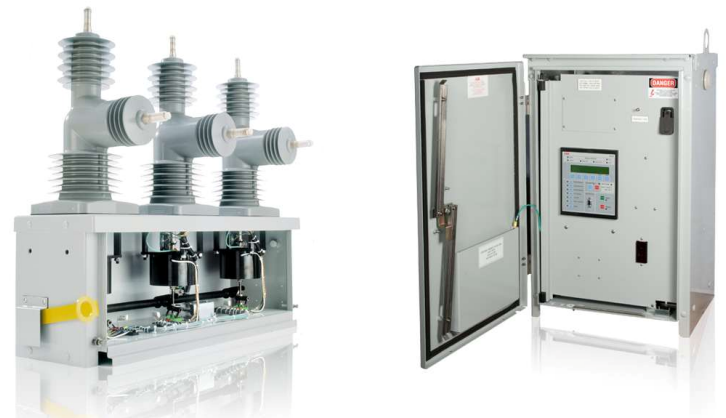

Gambar 1: Bentuk fisik recloser dan kotak peralatan kontrol

Secara garis besar cara kerja recloser adalah sebagai berikut [4]:

1. Arus yang mengalir normal ketika tidak terjadi gangguan.

2. Ketika terjadi gangguan, arus yang mengalir melalui recloser membuka dengan operasi "fast".

3. Kontak recloser akan menutup kembali setelah beberapa detik, sesuai dengan setting yang ditentukan. Tujuan memberikan selang waktu beberapa detik adalah memberi kesempatan agar gangguan tersebut hilang dari sistem, terutama gangguan yang bersifat temporer.

4. Jika yang terjadi adalah gangguan permanen, maka recloser akan membuka dan menutup balik sesuai setting yang ditentukan dan kemudian lock out atau membuka permanen.

5. Setelah gangguan permanen dibebaskan oleh teknisi lapangan, baru dapat dikembalikan pada kondisi normal.

\section{INDEKS KEANDALAN SISTEM DISTRIBUSI}

Indeks keandalan merupakan suatu indikator keandalan yang dinyatakan dalam suatu besaran probabilitas yang terdiri dari dari indeks titik beban dan indeks sistem yang dipakai untuk memperoleh pengertian yang mendalam ke dalam keseluruhan kinerja [6].

Laju kegagalan $(\lambda)$ adalah harga rata-rata dari jumlah kegagalan dalam suatu interval waktu tertentu. Ketidaktersediaan (U) adalah durasi gangguan dimana sistem tidak dapat menyuplai daya ke konsumen [7].
Untuk menghitung indeks keandalan penyulang per grup digunakan data indeks kegagalan peralatan sesuai SPLN No.59: 1985, "Keandalan Pada Sistem Distribusi 20 kV dan 6 kV" ditunjukkan pada tabel I [8]:

TABEL I

DATA INDEKS KEGAGALAN PERALATAN JARINGAN DISTRIBUSI

\begin{tabular}{|l|l|l|l|}
\hline Peralatan & $\lambda$ (kegagalan) & $\mathrm{r}$ (jam) & rs (jam) \\
\hline Saluran Udara & $0,2 \mathrm{~km} / \mathrm{tahun}$ & 3 & 0,15 \\
\hline Circuit Breaker & 0,004 unit/tahun & 10 & 0,15 \\
\hline Sectionalizer & 0,003 unit/tahun & 10 & 0,15 \\
\hline Trafo Distribusi & 0,005 unit/tahun & 10 & 0,15 \\
\hline
\end{tabular}

Parameter $\lambda$ dan $U$ digunakan untuk menghitung nilai keandalan pada setiap peralatan yang terdapat pada jaringan distribusi. Perhitungan $\lambda$ dan U pada setiap load point adalah:

- Failure Rate load point $\left(\lambda_{\mathrm{LP}}\right)$ merupakan nilai penjumlahan $\lambda$ tiap peralatan tenaga listrik yang ada pada jaringan distribusi seperti trafo distribusi, circuit breaker, maupun sectionalizer yang mempengaruhi titik beban yang sedang dihitung, sehingga didapatkan persamaannya sebagai berikut:

$$
\lambda_{\text {sys }}=\sum_{\mathrm{i}} \lambda \mathrm{i}
$$

- Unavailability load point $\left(\mathrm{U}_{\mathrm{LP}}\right)$ merupakan nilai perkalian antara $\lambda$ dengan $r$ masing-masing peralatan yang mempengaruhi titik beban yang dihitung, sehingga didapatkan persamaannya sebagai berikut:

$$
\mathrm{U}_{\mathrm{sys}}=\sum_{\mathrm{i}} \lambda \mathrm{i} . \mathrm{ri}
$$

Dimana :

$\lambda \mathrm{i}=\lambda$ untuk peralatan $\mathrm{i}$

ri $\quad=r$ untuk peralatan $\mathrm{i}$

Parameter indeks keandalan pada penelitian ini digunakan SAIDI dan SAIFI:

- SAIDI (System Average Interruption Duration Index) Indeks ini didefinisikan sebagai nilai rata-rata dari total jumlah waktu kegagalan untuk setiap konsumen per satuan waktu. Persamaannya adalah [5]:

$$
S A I D I=\frac{\sum U_{i} \cdot N_{i}}{\sum N_{i}}
$$

- SAIFI (System Average Interruption Frequency Index). Indeks ini didefinisikan sebagai jumlah rata-rata kegagalan yang terjadi per pelanggan yang dilayani oleh sistem per satuan waktu. Persamaannya adalah [5]:

Dimana : 


$$
\begin{array}{ll}
\sum \lambda_{i} \cdot N_{i} & =\text { jumlah perkalian antara } \lambda \text { dengan jumlah } \\
& \text { pelanggan komponen } i \\
\sum U_{i} \cdot N_{i} & =\text { jumlah perkalian antara } \mathrm{U} \text { dengan jumlah } \\
& \text { pelanggan komponen } i \\
\sum N_{i} & =\text { jumlah total pelanggan suatu sistem }
\end{array}
$$

\section{METODE VEGA}

Algoritma ini adalah penggabungan antara algoritma genetika dan infeksi virus. Algoritma genetika mempunyai siklus yang digambarkan seperti pada gambar 1. Tahap pertama dimulai dari membuat populasi awal secara acak, kemudian setiap individu dihitung nilai fitness-nya. Tahap selanjutnya adalah menyeleksi individu terbaik, kemudian dilanjutkan pada tahap reproduksi dengan melakukan crossover dan dilanjutkan oleh proses mutasi yang akan membentuk populasi baru. Setelah terbentuk populasi baru akan dilakukan tahap yang sama seperti populasi sebelumnya. Proses tersebut akan berlangsung hingga generasi yang ditentukan [9].

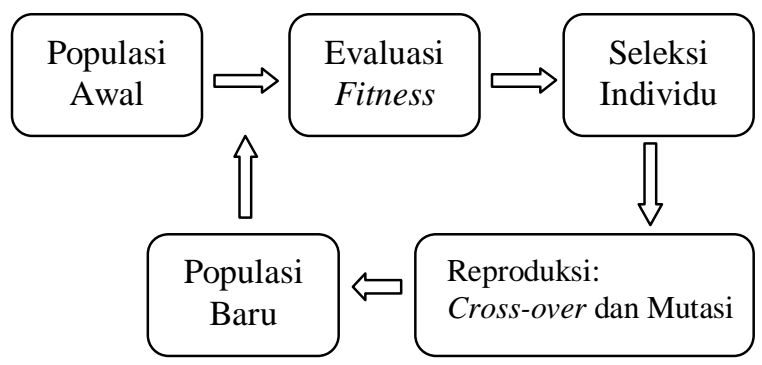

Gambar 2. Proses Algoritma genetika oleh David Goldberg

Proses lengkap algoritma genetika akan dijabarkan sebagai berikut [10]:

- Teknik pengkodean

Teknik pengkodean adalah bagaimana mengkodekan gen yang merupakan bagian dari kromosom. Kromosom sendiri merupakan alternatif solusi dari permasalahan yang akan dicari nilai optimalnya. Gen dapat direpresentasikan dalam bentuk bit, bilangan real, daftar aturan, elemen permutasi, elemen program atau representasi lainnya yang dapat diimplementasikan untuk operator genetika [9].

- Membangkitkan populasi awal

Nilai gen yang menyusun kromosom digunakan nilai laju kegagalan $(\lambda)$ dan waktu ketidaktersediaan (U) dengan rumus penyusun SAIDI dan SAIFI sebagai berikut:

$$
\begin{aligned}
& S A I D I_{1}=\frac{\lambda_{L 1} \cdot r_{L 1} \cdot m_{L 1}+\cdots+\lambda_{L n} \cdot r_{L n} \cdot m_{L n}}{m_{L 1}+m_{L 2}+\cdots+m_{L n}} \\
& S A I F I_{1}=\frac{\lambda_{L 1} \cdot m_{L 1}+\lambda_{L 2} \cdot m_{L 2}+\cdots+\lambda_{L n} \cdot m_{L n}}{m_{L 1}+m_{L 2}+\cdots+m_{L n}}
\end{aligned}
$$

- Nilai fitness

Nilai fitness merupakan nilai suatu individu yang dievaluasi berdasarkan suatu fungsi tertentu sebagai ukuran performansinya [11]. Tujuan dari permasalahan ini adalah meminimalkan nilai SAIDI dan SAIFI, sehingga fungsi fitness-nya dirumuskan sebagai berikut:

$$
f(x)=\frac{1}{S A I D I . S A I F I}
$$

Nilai fitness yang didapat dari hasil perhitungan berdasarkan persamaan 7 akan didapatkan populasi baru yang disebut populasi pertama. Hasil tersebut kemudian dilanjutkan ke tahap seleksi yaitu seleksi roulette wheel dan linier fitness ranking.

\section{- Roulette wheel}

Merupakan metode seleksi yang paling sering digunakan untuk memilih dua buah individu secara acak yang akan dijadikan orang tua.

- Linier Fitness Ranking (LFR)

Tujuan seleksi ini untuk menghindari terjadinya convergency premature yang disebabkan oleh suatu individu memiliki nilai fitness paling tinggi yang kemudian memproduksi banyak anak pada generasi tertentu melalui proses pindah silang dan mutasi sehingga menyebabkan lokal optimum.

- Pindah Silang (Cross Over)

Pindah Silang merupakan proses memindah-silangkan bagian kromosom Bapak dan Ibu yang dipotong satu titik secara random sehingga setengah nilai dari Bapak digunakan dan sisanya dilanjutkan dengan nilai dari Ibu.

- Mutasi

Proses mutasi yang digunakan pada penelitian ini adalah pengkodean nilai yang dapat dilakukan dengan berbagai cara, salah satunya yaitu dengan memilih sembarang posisi gen pada kromosom, nilai yang ada tersebut kemudian ditambah atau dikurangi dengan suatu nilai terkecil tertentu yang diambil secara acak.

Contoh:

Kromosom sebelum mutasi : $0,43 \quad 0,09 \quad 0,51 \quad 0,11 \quad 0,94$

Kromosom sesudah mutasi : $0,43 \quad 0,19 \quad 0,51 \quad 0,01 \quad 0,94$

- Kondisi selesai

Jika batasan nilai yang ditentukan telah terpenuhi, maka algoritma genetika akan menghentikan proses pencariannya, tetapi jika belum terpenuhi maka algoritma genetika akan kembali ke evaluasi fitness dan kembali mengulang proses dari awal sampai generasi ke-n.

Proses algoritma genetika dalam 1 generasi berakhir pada proses mutasi, pada metode VEGA proses algoritma genetika berjalan sampai proses mutasi kemudian mulai diinfeksi virus pada generasi 2 dan selanjutnya. VEGA disusun dari 2 populasi yakni populasi host dan populasi virus. Populasi host sama dengan populasi yang ada pada algoritma genetika yakni kandidat solusi. Sedangkan populasi virus adalah substring dari populasi host yang akan menginfeksi populasi host.

Komputasi metode VEGA dilakukan dengan 2 tahapan proses seperti pada gambar 3. Tahap pertama adalah mensimulasikan proses evolusi dengan pindah silang dan mutasi sehingga memungkinkan pewarisan sifat secara vertikal dari parent ke children. Tahap kedua adalah penginfeksian virus secara horizontal [3]. 
A. Pewarisan Sifat secara Vertikal

Inisialisasi host population pada metode VEGA sama dengan inisialisasi populasi pada GA. Inisialisasi virus population dilakukan dengan mengambil acak 3 host kromosom dari host population (7,5\% dari host population). Sedangkan inisialisasi gen virus dilakukan dengan generating incorporation. Pada generating incorporation, virus akan meng-copy beberapa bagian host gen secara acak, sesuai dengan copy probability-nya. Copy probability yang digunakan adalah 0,0001. Jika angka yang dibangkitkan secara acak kurang dari 0,001 maka gen host akan di-copy. Jika tidak, maka gen virus akan diisi dengan “*” (don't care). Proses seleksi, pindah silang, dan mutasi, prosesnya sama dengan GA.

B. Penginfeksian Virus secara Horizontal

Sesuai dengan diagram alir pada gambar 3 setelah proses algoritma genetika selesai yaitu proses mutasi, maka seluruh host individual bereproduksi sebagai children untuk diinfeksi virus.

- Penginfeksian Virus

Setiap virus menginfeksi host individual dengan reverse transcription sesuai dengan initial infection rate-nya. Initial infection rate ditentukan sebesar 0,01 . Pada reverse transcription, gen virus melakukan peng-copy-an ke gen host kecuali pada bagian yang ditandai dengan “*”.

- Fitness Virus

Fitness virus dihitung dengan persamaan 8 dan 9:

$$
\begin{aligned}
& \text { fitvirus }_{i j}=\text { fithost }_{j,}-\text { fithost }_{j} \\
& \text { fitvirus }_{i}=\sum_{j \in S} \text { fitvirus }_{i j}
\end{aligned}
$$

$$
\begin{aligned}
& \text { Dengan: } \\
& \text { fithost }_{\mathrm{j}} \quad \text { : harga fitness host individual } \mathrm{j} \text { sebelum } \\
& \text { penginfeksian virus } \\
& \text { fithost }_{\mathrm{j}}, \quad \text { : harga fitness host individual } \mathrm{j} \text { sesudah } \\
& \text { penginfeksian virus } \\
& \text { i : virus number } \\
& \text { S : satu set host individual yang diinfeksi } \\
& \text { oleh virus } \mathrm{i}
\end{aligned}
$$

Dari persamaan tersebut suatu virus dinyatakan produktif jika fitness virus-nya bernilai negatif, sebaliknya dinyatakan tidak produktif jika fitness virus-nya bernilai positif. Apabila fitness virus bernilai negatif maka infection rate-nya akan ditambahkan sesuai dengan persamaan 10 baris pertama. Sedangkan apabila fitness virus bernilai positif maka infection rate-nya akan dikurangi sesuai dengan persamaan 10 baris kedua.

$$
\text { Infrate }_{\mathrm{i}, t+1}=\left\{\begin{array}{l}
\left((1+\alpha) * \text { Infrate } \mathrm{i}, \mathrm{t}^{\prime}\right)+\text { Infrate } \mathrm{i}, \mathrm{t}, \mathrm{jika} \text { fitvirus }<0 \\
\left((1-\alpha) * \text { Infrate } \mathrm{i}, \mathrm{t}^{\prime}\right)+\text { Infrate } \mathrm{i}, \mathrm{t}, \mathrm{jika} \text { fitvirus }>0
\end{array}\right.
$$

Dengan: $\alpha \quad$ : koefisien berupa bilangan real dari $0-1$

$\mathrm{t} \quad$ : generation number

- Life Virus

Life virus dihitung menggunakan persamaan 11.

$$
\text { life }_{i, t+1}=r . \text { life }_{i, t}+\text { fitvirus }_{i}
$$

Dengan:

$\mathrm{r} \quad$ : life reduction yang harganya sudah ditentukan

Infection reduction akan memastikan jika virus benarbenar berevolusi secara produktif (makin negatif dari generasi sebelumnya). Life virus untuk virus produktif cenderung bernilai negatif sehingga makin lama bertahan dalam tiap generasi. Virus dengan kondisi seperti ini akan melakukan extending incorporation. Sedangkan untuk virus yang tidak produktif akan diberi kesempatan memperbaiki diri. Apabila life virus berkembang ke arah negatif, maka virus akan melakukan shortening incorporation. Sebaliknya jika life virus berkembang ke arah positif maka virus akan melakukan generating incorporation.

- Extending Incorporation

Pada extending incorporation, virus akan melakukan pengcopy-an hanya pada gen host yang ditandai dengan “*”. Copy probability yang digunakan pada penelitian ini sebesar 0,001. Jika angka acak yang dibangkitkan kurang dari copy probability, maka gen host akan di-copy. Jika tidak maka gen virus akan diisi dengan “*”, sama dengan gen virus awal.

- Shortening Incorporation

Pada shortening incorporation, virus akan melakukan penambahan gen "*” sesuai dengan cut probability-nya, kecuali pada gen yang mempunyai tanda “*”. Cut probability yang digunakan pada penelitian ini adalah sebesar 0,001. Jika angka acak yang dibangkitkan kurang dari cut probability, maka gen virus akan diisi dengan “*”. Jika tidak maka akan sama dengan gen virus awal.

- Generating Incorporation

Pada generating incorporation, virus akan meng-copy beberapa bagian gen host secara acak sesuai dengan copy probability-nya. Copy probability yang digunakan pada penelitian ini adalah sebesar 0,001. Jika angka acak yang dibangkitkan kurang dari copy probability, maka gen host akan di-copy. Jika tidak, maka gen virus akan diisi dengan “*”.

\section{METODE PENELITIAN}

Penelitian dilakukan di Laboratorium Analisa Sistem Tenaga Listrik Kampus Teknik Elektro Universitas Udayana dimulai dari bulan Mei hingga bulan September 2016. Data yang diperlukan diambil dari penelitian sebelumnya oleh Putra [2]. Pengambilan data yang sama dikarenakan hasil penelitian optimasi penempatan recloser menggunakan 
metode VEGA akan dibandingkan dengan penelitian Putra yang menggunakan metode kombinasi fuzzy GA. Data-data yang diperlukan berupa data single line diagram, jumlah beban, jumlah pelanggan, kapasitas trafo, panjang penyulang dan data gangguan. Alur penelitian dapat digambarkan dengan diagram alir pada gambar 3:

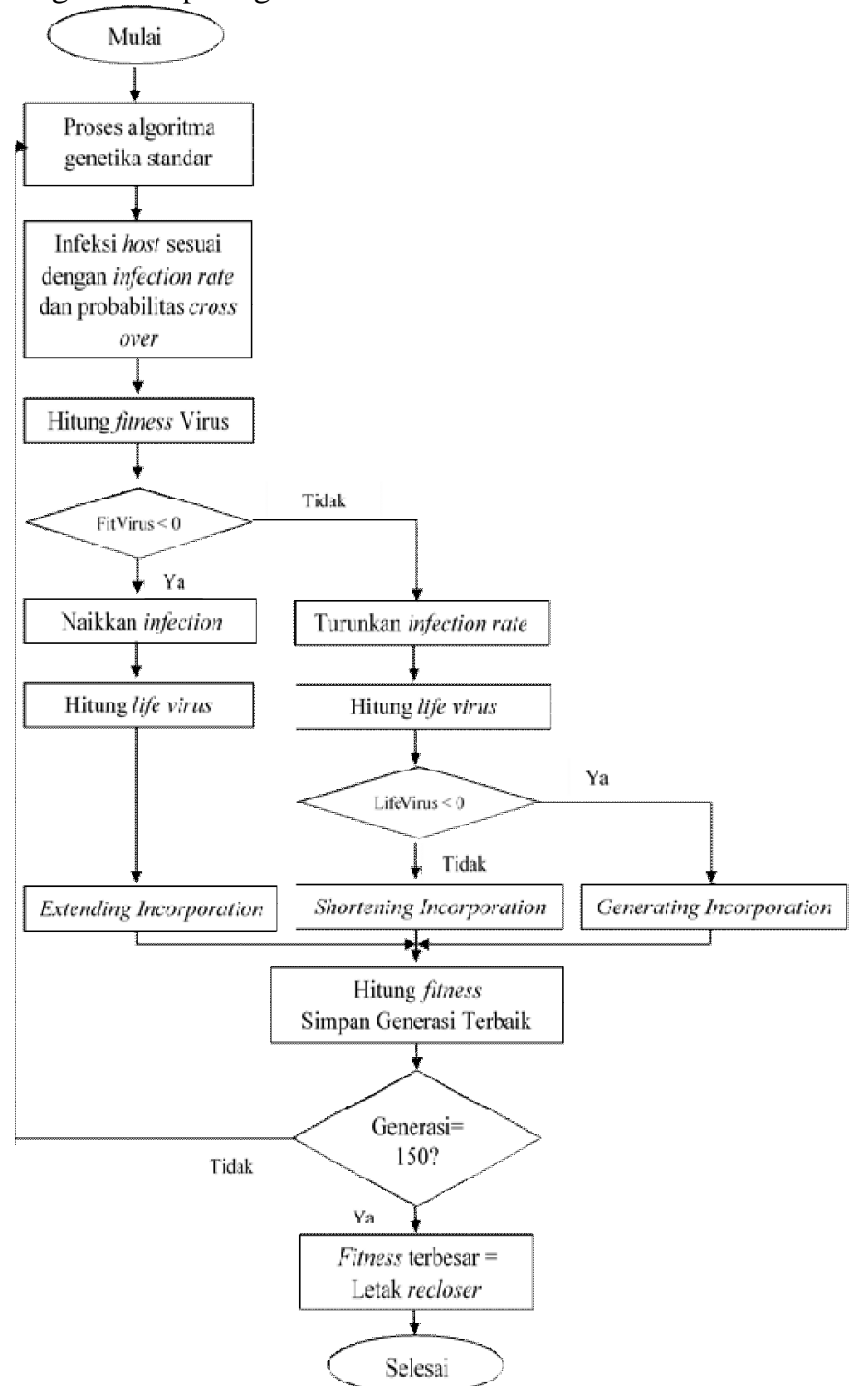

Gambar 3: Diagram alir optimasi penempatan recloser menggunakan metode VEGA

Tahapan penelitian sesuai diagram alir pada gambar 3 adalah sebagai berikut:

1. Mengumpulkan data jumlah pelanggan, single line diagram, data kapasitas trafo, data beban trafo, panjang saluran, laju kegagalan dan waktu keluaran.

2. Membagi penyulang lembongan menjadi 8 grup berdasarkan letak LBS.

3. Mencari nilai laju kegagalan, waktu keluaran dan ketidaktersedian tiap grup.

4. Menghitung nilai SAIDI dan SAIFI tanpa recloser.

5. Membangkitkan populasi dengan input-an load point penyulang Lembongan.
6. Memasukan nilai populasi awal ke fungsi fitness pada persamaan 7 dan mendapatkan nilai populasi pertama.

7. Melakukan proses linear fitness ranking.

8. Seleksi menggunakan roulette wheel.

9. Proses pindah silang (crossover) menggunakan tipe value encoding.

10. Melakukan proses mutasi dengan tipe mutasi pengkodean nilai dan mendapatkan nilai populasi baru.

11. Melakukan penginfeksian virus pada populasi baru

12. Menghitung fitness virus

13. Menghitung life virus

14. Menghitung fitness kemudian menyimpan generasi terbaik

15. Mengulang proses menghitung fitness sampai proses penginfeksian virus sampai generasi sama dengan jumlah generasi total generasi total yaitu 150 generasi.

16. Memilih 10 nilai fitness sebagai referensi letak recloser.

17. Memilih 1 nilai fitness terbaik sebagai letak recloser optimal.

Optimasi dimaksudkan untuk menentukan letak recloser pada penyulang Lembongan yang saat ini belum terpasang recloser. Fungsi tujuan dari permasalahan ini yaitu meminimalkan nilai SAIDI dan SAIFI penyulang Lembongan sesuai dengan persamaan 7. Batasan-batasan penelitiannya adalah data pelanggan sebelum dan sesudah optimasi diasumsikan sama, pembagian grup berdasarkan letak LBS, optimasi menggunakan 1 recloser, menggunakan 150 generasi pada program VEGA.

Program optimasi ini hanya menentukan 1 letak recloser optimal. Terdapat 8 grup yang merupakan kandidat penempatan recloser yang telah ditentukan berdasarkan letak LBS. Kandidat yang menunjukkan nilai SAIDI dan SAIFI minimal pada program optimasi VEGA merupakan penempatan recloser optimal, sehingga LBS yang telah terpasang akan digantikan oleh recloser.

\section{HASIL DAN ANALISIS}

Penyulang Lembongan menggunakan tipe konfigurasi jaringan radial. Penyulang ini memiliki 50 load point berupa trafo distribusi dengan total jumlah pelanggan 5038 dan total daya terpasang sebesar $6110 \mathrm{kVA}$. Penyulang Lembongan memiliki panjang saluran utama $21,770 \mathrm{~km}$ terbagi menjadi 8 grup berdasarkan letak LBS.

A. Perhitungan Keandalan Secara Manual

Tahap pertama yang dilakukan adalah menghitung keandalan penyulang Lembongan secara manual. Adapun tahapan perhitungannya sebagai berikut [12]:

1. Menyiapkan data panjang saluran, data jumlah pelanggan per load point dan data indeks kegagalan peralatan.

2. Menghitung laju kegagalan $(\lambda)$ yang dimulai dari grup 1 dan ketidaktersiediaan komponen (U) grup 1. Menghitung laju kegagalan $(\lambda)$ menggunakan persamaan 1 dan ketidaktersediaan (U) menggunakan persamaan 2. Tabel II merupakan hasil dari perhitungan manual $\lambda$ dan $U$ tiap load point: 
TABEL II

NILAI $\lambda$ DAN U GRUP 1

\begin{tabular}{|c|r|r|}
\hline Titik Beban & $\lambda$ & U \\
\hline LP1 & 0.1236 & 0.2718 \\
\hline LP2 & 0.2912 & 1.0555 \\
\hline LP3 & 0.1622 & 0.2454 \\
\hline LP4 & 0.4001 & 0.4327 \\
\hline LP5 & 1.3663 & 1.8907 \\
\hline LP6 & 1.0435 & 3.0171 \\
\hline LP7 & 0.9962 & 1.7973 \\
\hline
\end{tabular}

3. Mengalikan hasil dari laju kegagalan $(\lambda)$ dan ketidaktersediaan (U) dengan jumlah pelanggan dari masing-masing load point ditunjukkan pada tabel III.

TABEL III

NILAI $\lambda$ x PELANGGAN DAN U x PELANGGAN GRUP 1

\begin{tabular}{|c|r|r|}
\hline Titik Beban & $\boldsymbol{\lambda}$ x pelanggan & \multicolumn{1}{|c|}{ U x pelanggan } \\
\hline LP1 & 39.4375 & 86.7015 \\
\hline LP2 & 4.0766 & 14.7776 \\
\hline LP3 & 26.9203 & 40.7295 \\
\hline LP4 & 0.4001 & 0.4327 \\
\hline LP5 & 215.8763 & 298.7268 \\
\hline LP6 & 158.6070 & 458.6037 \\
\hline LP7 & 42.8372 & 77.2850 \\
\hline TOTAL & 488.1549 & 977.2567 \\
\hline
\end{tabular}

4. Menghitung dengan cara yang sama seperti langkah 2 dan 3 pada grup 2 sampai grup 8 .

5. Menjumlahkan nilai total $\lambda \mathrm{x}$ pelanggan dan nilai total $\mathrm{U} \mathrm{x}$ pelanggan dari grup 1 sampai grup 8 serta menjumlahkan seluruh pelanggan penyulang Lembongan dari grup 1 sampai grup 8, ditunjukkan pada tabel IV.

TABEL IV

NILAI KEANDALAN PENYULANG LEMBONGAN

\begin{tabular}{|c|c|c|c|}
\hline \multirow{2}{*}{ Grup } & \multicolumn{2}{|c|}{ Indeks Keandalan Sistem } & \multirow{2}{*}{$\begin{array}{c}\text { Jumlah } \\
\text { Pelanggan }\end{array}$} \\
\cline { 2 - 3 } & $\lambda$ x pelanggan & U x pelanggan & 853 \\
\hline 1 & 488.155 & 977.257 & 1327 \\
\hline 2 & $3,442.215$ & $3,442.215$ & 92 \\
\hline 3 & 53.905 & 86.619 & 894 \\
\hline 4 & 881.696 & $1,237.560$ & 523 \\
\hline 5 & 20.513 & 70.852 & 74 \\
\hline 6 & 1.182 & 7.730 & 1104 \\
\hline 7 & 652.106 & $1,053.908$ & 171 \\
\hline 8 & 12.234 & 32.924 & $\mathbf{5 0 3 8}$ \\
\hline Total & $\mathbf{5 . 5 5 2 . 0 0 6}$ & $\mathbf{8 . 2 3 8 . 3 5 6}$ & \\
\hline
\end{tabular}

6. Menghitung indeks keandalan sistem menggunakan persamaan 3 untuk SAIDI dan persamaan 4 untuk SAIFI :
Perhitungan SAIDI (System Average Interruption Duration Index) :

SAIDI

$$
\begin{aligned}
& =\frac{\sum U_{i} \cdot N_{i}}{\sum N_{i}} \\
& =\frac{\mathbf{8 , 2 3 8 . 3 5 6}}{\mathbf{5 0 3 8}}=1.635 \mathrm{jam} / \text { pelanggan } / \text { tahun }
\end{aligned}
$$

Perhitungan SAIFI (System Average Interruption Frequency Index) :

$$
\begin{aligned}
\text { SAIFI } & =\frac{\sum \lambda_{i} \cdot N_{i}}{\sum N_{i}} \\
& =\frac{\mathbf{5 , 5 5 2 . 0 0 6}}{\mathbf{5 0 3 8}}=1.102 \mathrm{kali} / \text { pelanggan } / \text { tahun }
\end{aligned}
$$

Nilai keandalan dari perhitungan manual nantinya akan dibandingkan dengan hasil penelitian sebelumnya yang dilakukan oleh Putra menggunakan metode kombinasi fuzzy GA serta dibandingkan dengan penelitian menggunakan metode VEGA.

B. Perhitungan Keandalan Menggunakan Metode VEGA

Hasil dari program optimasi penempatan recloser menggunakan metode VEGA pada penyulang Lembongan dengan nilai fitness paling tinggi dari running program ke-7 dapat dilihat pada gambar 4 .

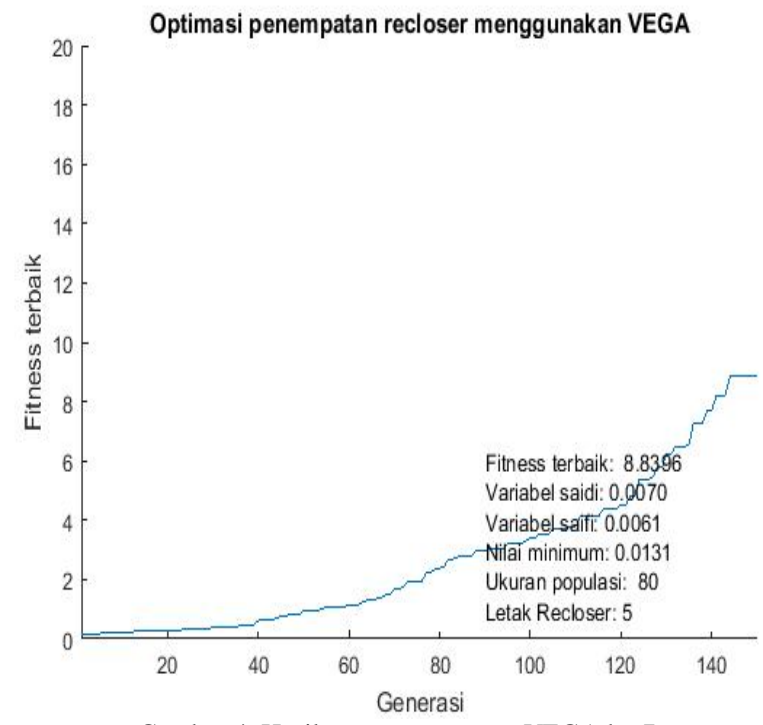

Gambar 4. Hasil running program VEGA ke-7

Hasil dari 10 kali running program VEGA selengkapnya dapat dilihat pada tabel V. 
TABEL V

HASIL RUNNING PROGRAM VEGA

\begin{tabular}{|c|c|c|c|c|c|c|}
\hline No. & Fitness & SAIDI & SAIFI & Grup & $\begin{array}{c}\text { Running } \\
\text { Program } \\
\text { ke- }\end{array}$ & $\begin{array}{c}\text { Waktu } \\
\text { Running } \\
\text { (detik) }\end{array}$ \\
\hline 1 & 8,8396 & 0,0070 & 0,0061 & 5 & 7 & 217 \\
\hline 2 & 8,7940 & 0,0105 & 0,0032 & 5 & 2 & 218 \\
\hline 3 & 8,7390 & 0,0045 & 0,0099 & 5 & 9 & 221 \\
\hline 4 & 8,6889 & 0,0101 & 0,0050 & 5 & 4 & 220 \\
\hline 5 & 8,5596 & 0,0154 & 0,0014 & 5 & 5 & 220 \\
\hline 6 & 8,1316 & 0,0014 & 0,0216 & 5 & 8 & 221 \\
\hline 7 & 8,1124 & 0,0028 & 0,0205 & 4 & 10 & 220 \\
\hline 8 & 7,9281 & 0,0098 & 0,0163 & 5 & 3 & 223 \\
\hline 9 & 7,7263 & 0,0160 & 0,0134 & 5 & 1 & 222 \\
\hline 10 & 7,1457 & 0,0186 & 0,0214 & 5 & 6 & 217 \\
\hline
\end{tabular}

Berdasarkan tabel $\mathrm{V}$, hasil dari 10 kali running program metode VEGA menunjukkan letak recloser optimal berada pada grup 5 dengan kemunculan sebanyak 9 kali pada grup 5 dan hanya 1 kali pada grup 4. Selain itu fitness tertinggi 8,8396 juga menunjukkan letak recloser berada pada grup 5 dengan SAIDI 0,0070 dan SAIFI 0,0061. Hasil running program dengan fitness tertinggi didapatkan dari running program ke-7 dengan durasi running program selama 217 detik atau sekitar 3,6 menit.

Berdasarkan hasil analisis setelah penempatan recloser pada grup 5 telah menunjukkan lokasi yang tepat, jika dilihat dari jumlah pelanggan yang terlindungi dan impedansi jaringan. Posisi recloser pada grup 5 mampu melindungi 3.689 pelanggan dari 5.038 total pelanggan dan impedansi jaringan dapat disebutkan bahwa panjang saluran utama berkurang dari $21,770 \mathrm{~km}$ menjadi $17,311 \mathrm{~km}$ yaitu dari grup 1 sampai grup 5 .

Perbandingan nilai keandalan dari perhitungan manual, metode kombinasi fuzzy GA, dan metode VEGA dapat dilihat pada tabel VI. Dasar perbandingan hasil optimasi program metode VEGA dengan metode kombinasi fuzzy GA dikarenakan kedua penelitian tersebut menggunakan data yang sama yaitu penyulang Lembongan agar hasil nilai SAIDI dan SAIFI dapat dibandingkan.

TABEL VI

PERBANDINGAN NILAI KEANDALAN PERHITUNGAN MANUAL, METODE KOMBINASI FUZZY GA DAN METODE VEGA

\begin{tabular}{|c|c|c|c|c|}
\hline Metode & Fitness & SAIDI & SAIFI & $\begin{array}{c}\text { Waktu Running } \\
\text { (detik) }\end{array}$ \\
\hline $\begin{array}{c}\text { Perhitungan } \\
\text { Manual } \\
\text { dengan } \\
\text { Recloser }\end{array}$ & - & 1,635 & 1,102 & - \\
\hline $\begin{array}{c}\text { Metode } \\
\text { Kombinasi } \\
\text { fuzzy GA }\end{array}$ & 3,9639 & 0,069 & 0,092 & 15 \\
\hline Metode VEGA & 8,8396 & 0,007 & 0,006 & 217 \\
\hline
\end{tabular}

Berdasarkan tabel VI, terlihat bahwa perbandingan nilai keandalan (SAIDI dan SAIFI) menggunakan metode VEGA semakin meningkat dibandingkan menggunakan metode kombinasi fuzzy GA, namun waktu yang dibutuhkan untuk running program metode VEGA lebih lama karena pada metode VEGA terdapat penginfeksian virus yang membuat adanya perhitungan tambahan sehingga perhitungan semakin kompleks. Hasil penempatan recloser yang optimal yang ditunjukkan oleh metode kombinasi fuzzy GA dibandingkan dengan metode VEGA sama yaitu pada grup 5, namun metode VEGA memiliki nilai keandalan (SAIDI dan SAIFI) yang lebih baik dibandingkan menggunakan metode kombinasi fuzzy GA. Hal tersebut diakibatkan metode VEGA memiliki proses penginfeksian virus untuk memperbaiki nilai individu setiap generasi.

\section{KESIMPULAN}

Berdasarkan hasil analisis dan pembahasan optimasi penempatan recloser menggunakan metode VEGA pada penyulang Lembongan dapat disimpulkan bahwa penempatan recloser optimal berada pada grup 5 berdasarkan program yang memunculkan 9 kali pada grup 5 dari 10 kali running program. Nilai fitness tertinggi mencapai 8,8396 dengan SAIDI 0,0070 dan SAIFI 0,0061. Nilai keandalan tersebut membuktikan recloser mampu meningkatkan keandalan jauh lebih baik dibandingkan sebelum pemasangan recloser dengan indeks keandalan sebelumnya yaitu SAIDI 95,85 jam/ pelanggan/ tahun dan SAIFI 76 kali/ pelanggan/ tahun. Penempatan recloser pada grup 5 juga terbukti mampu melindungi 3.689 pelanggan dari 5.038 total pelanggan dan mampu mengurangi impedansi jaringan dari $21,770 \mathrm{~km}$ menjadi 17,311 km yaitu dari grup 1 sampai grup 5. Hasil perbandingan penempatan recloser optimal menggunakan metode VEGA dan metode kombinasi fuzzy GA sama yaitu pada grup 5. Perbandingan waktu yang dibutuhkan untuk running program metode VEGA sekitar 3,6 menit sedangkan metode kombinasi fuzzy GA hanya 15 detik. Metode VEGA memiliki kelemahan pada waktu running program yang lebih lama sekitar 14 kali lipat lebih lama dari metode kombinasi fuzzy GA.

\section{REFERENSI}

[1] Hartati, R. S., Sukerayasa, I. W. "Penerapan Metode Pendekatan Teknik untuk Meningkatkan Keandalan Sistem Distribusi”. Teknologi Elektro, Vol.9, No.1, (Januari-Juni) : 50-53. 2010.

[2] Putra, I. M. Y. L. "Optimasi Penempatan Recloser untuk Memperbaiki Keandalan Sistem Distribusi pada Penyulang Lembongan Menggunakan Metode Kombinasi Logika Fuzzy dengan Algoritma Genetika". Teknologi Elektro dan Komputer, Vol. 15, No.1, (JanuariJuni) : 2016

[3] Amrita, A.A.N. 2007. Penentuan Posisi dan Kapasitas Optimal Bank Kapasitor pada Sistem Distribusi Menggunakan Virus Evolutionary Genetic Algorithm (VEGA). Surabaya: Institut Teknologi Sepuluh November Surabaya.

[4] PT. PLN (Persero). 1997. PBO-SSO. Jakarta: PT.PLN (Persero) Pusat Pendidikan dan Pelatihan. 
[5] NN. 2017. OVR ANSI / IEC MV outdoor vacuum reclosers. http://new.abb.com/medium-voltage/apparatus/reclosers/ansi-iec-

single-and-three-phase-recloser-ovr. Diakses tanggal 15 April 2017.

[6] Marsudi, D. 2006. Operasi Sistem Tenaga Listrik. Yogyakarta: Graha Ilmu

[7] Brown.R. 2009. Electric Power Distribution Reliability, Second Edition, New York, CRC Press Tylor \& Francis Group.

[8] PT. PLN (Persero). 1985. Keandalan Pada Sistem Distribusi 20 kV dan 6 kV. Jakarta: SPLN No.59: 1985.

[9] Sutojo, dkk. 2010. Kecerdasan Buatan. Semarang: Andi.

[10] Zukhri. Z. 2013. Algoritma Genetika Metode Komputasi Evolusioner untuk Menyelesaikan Masalah Optimasi, Yogyakarta, Andi.

[11] Suyanto. 2005. Algoritma Genetika dalam MATLAB. Yogyakarta, Andi

[12] Arigandi, G. P. B., Hartati, R. S., Weking, A. I. "Analisa Keandalan Sistem Distribusi Penyulang Kampus dengan Menggunakan Penggabungan Metode Section Tecknique Dan Ria". Teknologi Elektro, Vol. 14, No.2, (Juli-Desember) : 1-5. 2015. 